\title{
Relationships of stable carbon isotopes, plant water potential and growth: an approach to asses water use efficiency and growth strategies of dry land agroforestry species
}

\author{
Aster Gebrekirstos • Meine van Noordwijk • \\ Henry Neufeldt • Ralph Mitlöhner
}

Received: 8 February 2010/Revised: 16 May 2010/ Accepted: 8 July 2010/Published online: 3 August 2010

(C) The Author(s) 2010. This article is published with open access at Springerlink.com

\begin{abstract}
The relationships between annual wood stable carbon isotope composition $\left(\delta^{13} \mathrm{C}\right)$, dry season midday plant water potential, and annual growth rate were investigated to asses the ability of agroforestry species to adapt to climate changes. 6-8 stem disks from four co-occurring species (Acacia senegal, A. seyal, A. tortilis and Balanites aegyptiaca) were collected for radial growth measurements using tree-ring analysis spanning 1930-2003. Annual $\delta^{13} \mathrm{C}$ was measured on three tree disks per species for the period 1970-2002. Midday plant water potential was measured during the dry season. Annual radial growth and midday plant water potential ranged from 0.27 to $9.12 \mathrm{~mm}$ and -1.0 to $-5.0 \mathrm{MPa}$, respectively, with statistically significant differences. After correcting annual wood $\delta^{13} \mathrm{C}$ for atmospheric changes in $\delta^{13} \mathrm{C}$, carbon isotopic composition ranged from -22.22 to $-26.58 \%$. Relationships between $\delta^{13} \mathrm{C}$, radial growth and plant water potentials revealed the interaction of water availability, stomatal conductance, $\delta^{13} \mathrm{C}$ values and growth. Two contrasting water use strategies and competitive advantages can be distinguished. Species with lower mean $\delta^{13} \mathrm{C}$ values $(A$. senegal and A. seyal) show high plant water potential and, hence, better growth during moist years. Thus, they indicate low water
\end{abstract}

Communicated by A. Bräuning.

Contribution to the special issue "Tropical Dendroecology".

A. Gebrekirstos $(\square) \cdot$ M. van Noordwijk $\cdot$ H. Neufeldt

World Agroforestry Centre, P.O. Box 30677-00100,

Nairobi, Kenya

e-mail: agebrekirstos@yahoo.com; A.Gebrekirstos@cgiar.org

A. Gebrekirstos · R. Mitlöhner

Institute of Silviculture, Sect. II: Tropical Silviculture,

Georg-August University of Göttingen,

37077 Göttingen, Germany use efficiency (WUE) and opportunistic water use strategy. On the other hand, species with lower water potentials (A. tortilis and B. aegyptiaca) showed relative better growth performance and less increase in $\delta^{13} \mathrm{C}$ in drought years, reflecting their high WUE and conservative water use strategy. These results suggest that $\delta^{13} \mathrm{C}$ in tree rings can be useful in estimating historic changes in plant WUE and hence in screening drought tolerant species in the face of expected climate changes, as well as for assessing the functional diversity and risk reduction in mixed vegetation.

Keywords Climate change - Dendrochronology · Drought tolerance - Ethiopia - Water use efficiency . Tree rings

\section{Introduction}

Global climate change is expected to modify patterns of rainfall variability and the composition of vegetation responds to that, especially in dry regions of Africa (IPCC 2007). Assessment of vegetation level vulnerability, climate change resilience and human adaptation options requires understanding of the diversity, among tree species in the current vegetation, of genetic and phenotypic growth strategies and response to fluctuating water availability (Dawson et al. 2009). Human livelihoods in many parts of Africa depend on the use and management of trees in forms of dryland agroforestry (Poschen 1986). Acacias and close relatives are important agroforestry species and major components of the vegetation in arid and semi-arid parts of Africa. There is a wide range of life history and phenology traits in this group, hence tree water use and water use efficiency (WUE) must also be determined to support decision-making in tree domestication and reforestation 
efforts. For instance, under drought prone conditions, species with a wide capacity to withstand hydrological changes may be an advantage while species with better growth performance could be suitable in areas of nonlimiting water conditions. This is imperative especially in countries such as Ethiopia where previous reforestation programs, attempted to counteract the effects of deforestation, have failed mainly due to lack of knowledge on the ecology and adaptation to environmental stress (Gebrekirstos 2006).

An important physiological trait related to water use and stomatal behavior under drought conditions is the ratio of internal to ambient $\mathrm{CO}_{2}$ concentration $\left(C_{\mathrm{i}} / C_{\mathrm{a}}\right)$ of leaves (Farquhar et al. 1989). The stomata are not only the gates for carbon dioxide diffusion into the intracellular leaf space but also control water loss due to water vapor diffusion out of the leaf (transpiration). A number of environmental factors exert stress on plants, which can affect the rate of photosynthesis or stomatal conductance, and thus influence $C_{\mathrm{i}}$ and carbon isotope ratio $\left(\delta^{13} \mathrm{C}\right)$ in plant matter. Therefore, growth, plant water potential and stable carbon isotopes were considered simultaneously as a measure of stress tolerance. The carbon isotope ratio $\left(\delta^{13} \mathrm{C}\right)$ of plants is isotopically depleted in ${ }^{13} \mathrm{C}$ with respect to atmospheric $\mathrm{CO}_{2}$ (Farquhar et al. 1989). According to Farquhar et al. (1982), isotopic composition is a function of isotopic fractionation associated with differential diffusivities of ${ }^{13} \mathrm{CO}_{2}$ versus ${ }^{12} \mathrm{CO}_{2}$ in the air and stomata $(a=4.4 \%$ ) and the net fractionation by Rubisco during the photosynthetic $\mathrm{CO}_{2}$ fixation reaction $(b=27 \%)$, the ratio of the intercellular $\left(C_{\mathrm{i}}\right)$ to atmospheric $\mathrm{CO}_{2}\left(C_{\mathrm{a}}\right)$ concentration $\left(C_{\mathrm{i}} / C_{\mathrm{a}}\right)$ and the current $\delta^{13} \mathrm{C}$ value of the atmosphere $(-8 \%)$ expressed as:

$\delta^{13} \mathrm{C}=\delta^{13} \mathrm{C}_{\mathrm{atm}}-a-(b-a)\left(C_{\mathrm{i}} / C_{\mathrm{a}}\right)$.

A broad relationship exists between carbon isotope composition of plant dry matter and the efficiency with which this dry matter is produced relative to the amounts of water which the plant transpires (Farquhar et al. 1989). A significant positive correlation has been found between $\delta^{13} \mathrm{C}$ and WUE both theoretically and empirically (Farquhar et al. 1982, 1989). Net instantaneous WUE, the ratio of carbon assimilation to evapo-transpiration, has been found to co-vary with $\delta^{13} \mathrm{C}$ in a sense that high $\delta^{13} \mathrm{C}$ values correspond to high WUE and vice versa (Farquhar et al. 1988). Plants can achieve high WUE through either low transpiration, or high net photosynthesis, or both. Since both water and $\mathrm{CO}_{2}$ diffuse through the stomata, traits that determine isotopic composition of plant tissues have important implications for transpiration, productivity and plant survival in water limited environments (Ehleringer 1993).

Plant water potential also plays a key role in connecting water uptake, leaf hydration status (Vertovec et al. 2001) stomatal closure, opportunities for cell wall expansion (Macfarlane and Adams 1998) and the total use and allocation of photosynthate for growth of various organs (Breda et al. 1993). More drought-resistant species tend to reach low water potentials more rapidly than less resistant species (Ladiges 1975). On the basis of the diurnal range in plant water potential (predawn, midday), Gebrekirstos et al. (2006) classified Acacia senegal and A. seyal into drought avoiders and $A$. tortilis and Balanites aegyptiaca as drought tolerant in Ethiopia. The latter two species had lower (more negative) midday plant water potential. In addition to plant water potential, however, study of interannual variation through tree ring growth and isotope composition adds a further dimension and allows to scale up to the life time of trees (Gebrekirstos 2006). The tradeoffs between avoidance and tolerance at interannual scales can be linked to their WUE across the range of climatic conditions that may have occurred over the life time of the tree. Hence, to further explore the water use strategy of the four tree species studied by Gebrekirstos et al. (2006), we synthesized three approaches that provide different information about drought response: (a) midday plant water potential values during the dry season, as a measure of plant response to water stress (as described by Gebrekirstos et al. 2006), (b) radial growth spanning 1930-2002 as a measure of growth response under changing water availability (as described by Gebrekirstos et al. 2008), (c) $\delta^{13} \mathrm{C}$ in tree rings for the period 1970-2002 as a measure of change in WUE in response to rainfall amount. Our specific objectives were (a) to determine if correlations exist between carbon isotope ratios, plant water potential and radial growth, (b) to use these relationships to characterize species-specific water use strategy and tolerance to moisture stress in the face of climate change.

\section{Materials and methods}

\section{Study area}

The study area, Abernosa ranch, is located within the upper Rift Valley Lakes Sub region, $170 \mathrm{~km}$ south of Addis Ababa, $7^{\circ} 51^{\prime} \mathrm{N}$ to $38^{\circ} 42^{\prime} \mathrm{E}$ at an elevation of about $1,600 \mathrm{~m}$. The area is classified as semi-arid eco-climatic vegetation zone (Makin et al. 1975) and is a major part of the country's Acacia woodland and savanna region.

The climate of the area is characterized by a distinct dry season. The long and short rainy periods occur from July to September and April to June, respectively. The wettest month is July with an average precipitation of $142 \mathrm{~mm}$. Average annual precipitation, measured at Adami Tulu Research Center Meteorological Station, amounts to $760 \mathrm{~mm}$ and ranges between 550 and $900 \mathrm{~mm}$ (Fig. 1). 


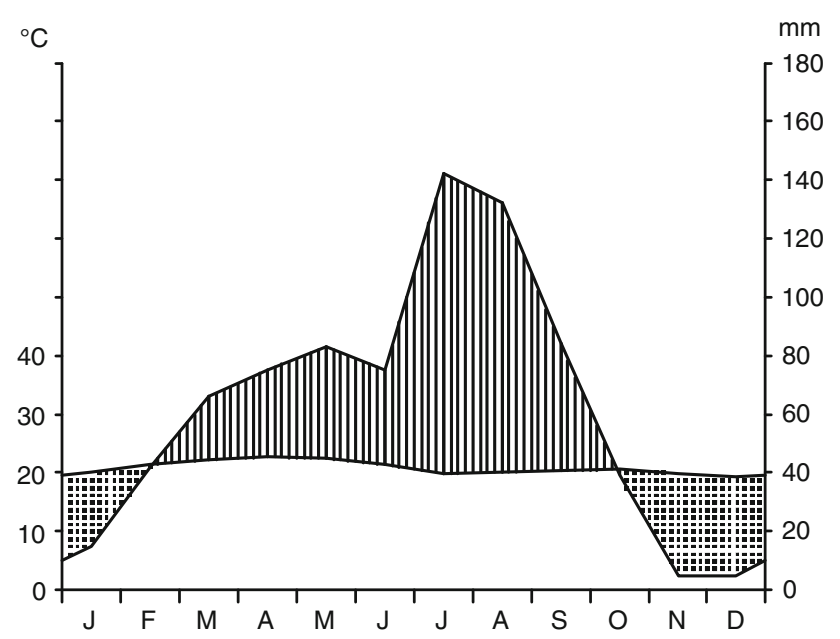

Fig. 1 Climatic diagram of the study sites (in Abernosa) drawn according to Walter (1973). Rainfall and temperature data (1980-2002) were obtained from Adamitulu Research Meteorological Station, which is situated at about $5 \mathrm{~km}$ from Abernosa

Mean annual temperature is $20.7^{\circ} \mathrm{C}$ and varies little from year to year. The soils are sandy loam with $\mathrm{pH}$ of 6.75 .

Study species descriptions

The study species are Acacia tortilis (Forssk.) Hayne, Acacia seyal Del, Acacia senegal (L.) Wild., and Balanites aegyptiaca (L.) Del. The Acacias are drought deciduous and are members of Fabaceae family, while the evergreen Balanites aegyptiaca belongs to Balanitaceae. Acacias provide important ecological and economical services for local communities all over Africa. The habitat/ecology, geographical distribution and uses of the study species are reported in detail elsewhere (Azene-Bekele et al. 1993; Hedberg and Edwards 1989; van Noordwijk 1984).

According to long-term climate-growth analysis of the species by Gebrekirstos et al. (2008), tree ring width varied considerably $(0.27-9.12 \mathrm{~mm}$ ) between years and among the species. Higher growth rates in all the species were related to moist years (Table 1). A study on plant water potential parameters, using a pressure chamber (Scholander et al. 1965), at sites with different biophysical settings and diurnal differences also revealed significant differences among the species (Gebrekirstos et al. 2006). The habit, midday plant water potentials and annual radial growth characteristics are summarized in Table 1.

Stable carbon isotopes

Three stem disks per species were selected from the tree disks that had been used for the tree-ring analysis. Individual $\delta^{13} \mathrm{C}$ series measurements were performed on bulk wood with annual resolution for the years 1973-2002. The stable carbon isotopic signatures of the wood samples were measured online using an NA 2500 elemental analyzer (CE Instruments, Rodano, Italy), linked with an isotope ratio mass spectrometer (Finnigan MAT Delta plus, Bremen, Germany) via a ConFlo III interface at the Center for Stable Isotope Research and Analysis, Forest Ecosystem Research, University of Göttingen, Germany. The internal reproducibility of the mass spectrometer was $0.1-0.15 \%$. The standard deviation of $\delta^{13} \mathrm{C}$ for the repeated analysis of NBS 21 (Graphite) was $0.07 \%$. Variations of isotope ratios are expressed in $\delta$-notation, i.e. the relative deviation from the PDB standard and given as: $\delta{ }^{13} \mathrm{C}=\left[\left({ }^{13} \mathrm{C} /{ }^{12} \mathrm{C}\right)\right.$ sample/ $\left.\left.\left({ }^{13} \mathrm{C} /{ }^{12} \mathrm{C}\right) \mathrm{PDB}\right)-1\right] \times 1,000 \%$.

\section{Data analysis}

Tree-ring isotopic data contain trends and variability unrelated to past climate. One non-climatic trend that can be removed from $\delta^{13} \mathrm{C}$ series is related to the decline in atmospheric $\delta^{13} \mathrm{C}$ values caused by burning of fossil fuels. This trend was removed following the method described in McCarroll and Loader (2004). However, the strong declining trend on series of B. aegyptiaca after 1992 remains in our records even after correcting for change in $\delta^{13} \mathrm{C}$ air (Fig. 2). The $\delta^{13} \mathrm{C}$ values were averaged into mean, maximum and minimum values. According to rainy season precipitation amount, the $\delta^{13} \mathrm{C}$ values (1973-2002) were allocated into drought (11 years) and moist years (19 years).

To determine the relationships between radial growth, plant water potential and $\delta^{13} \mathrm{C}$ variations, we considered

Table 1 List of studied species with summary of their habit, midday plant water potential values and annual growth increments

\begin{tabular}{|c|c|c|c|c|c|}
\hline \multirow[t]{2}{*}{ Species } & \multirow[t]{2}{*}{ Habit } & \multirow{2}{*}{$\begin{array}{l}\text { Midday plant water } \\
\text { potential }(\mathrm{MPa})\end{array}$} & \multicolumn{3}{|c|}{ Annual radial growth $(\mathrm{mm})$} \\
\hline & & & Mean & Maximum & Minimum \\
\hline A. senegal & Deciduous tree, up to $10-15 \mathrm{~m}$ & $-2.14 \pm 0.17 \mathrm{a}$ & $2.53 \pm 0.35 \mathrm{a}$ & $9.12 \pm 0.92 \mathrm{a}$ & $0.30 \pm 0.15 \mathrm{a}$ \\
\hline A. seyal & Deciduous tree up to $9 \mathrm{~m}$ & $-2.41 \pm 0.17 \mathrm{a}$ & $2.32 \pm 0.66 \mathrm{a}$ & $7.89 \pm 1.85 \mathrm{a}$ & $0.27 \pm 0.13 \mathrm{a}$ \\
\hline A. tortilis & Deciduous tree, $4-21 \mathrm{~m}$ & $-3.05 \pm 0.17 b$ & $1.81 \pm 0.46 \mathrm{a}$ & $5.25 \pm 1.64 \mathrm{~b}$ & $0.34 \pm 0.29 \mathrm{a}$ \\
\hline B. aegyptiaca & Evergreen small tree up to $8 \mathrm{~m}$ & $-4.61 \pm 0.17 \mathrm{c}$ & $1.93 \pm 0.30 \mathrm{a}$ & $4.58 \pm 0.74 b$ & $0.40 \pm 0.14 \mathrm{a}$ \\
\hline
\end{tabular}

The values of midday plant water potentials and annual radial increment are from Gebrekirstos et al. 2006, 2008, respectively. Within a column, means followed by different letters were statistically different at $P<0.05$ 
Fig. 2 a Rainy season precipitation indices (JuneSeptember), b ring width indices (each of the species curves represents the mean of six trees), c inter-annual pattern of $\delta^{13} \mathrm{C}$ signature measured on bulk wood of four co-occurring tree species (each of the species curves represents the mean of three trees)

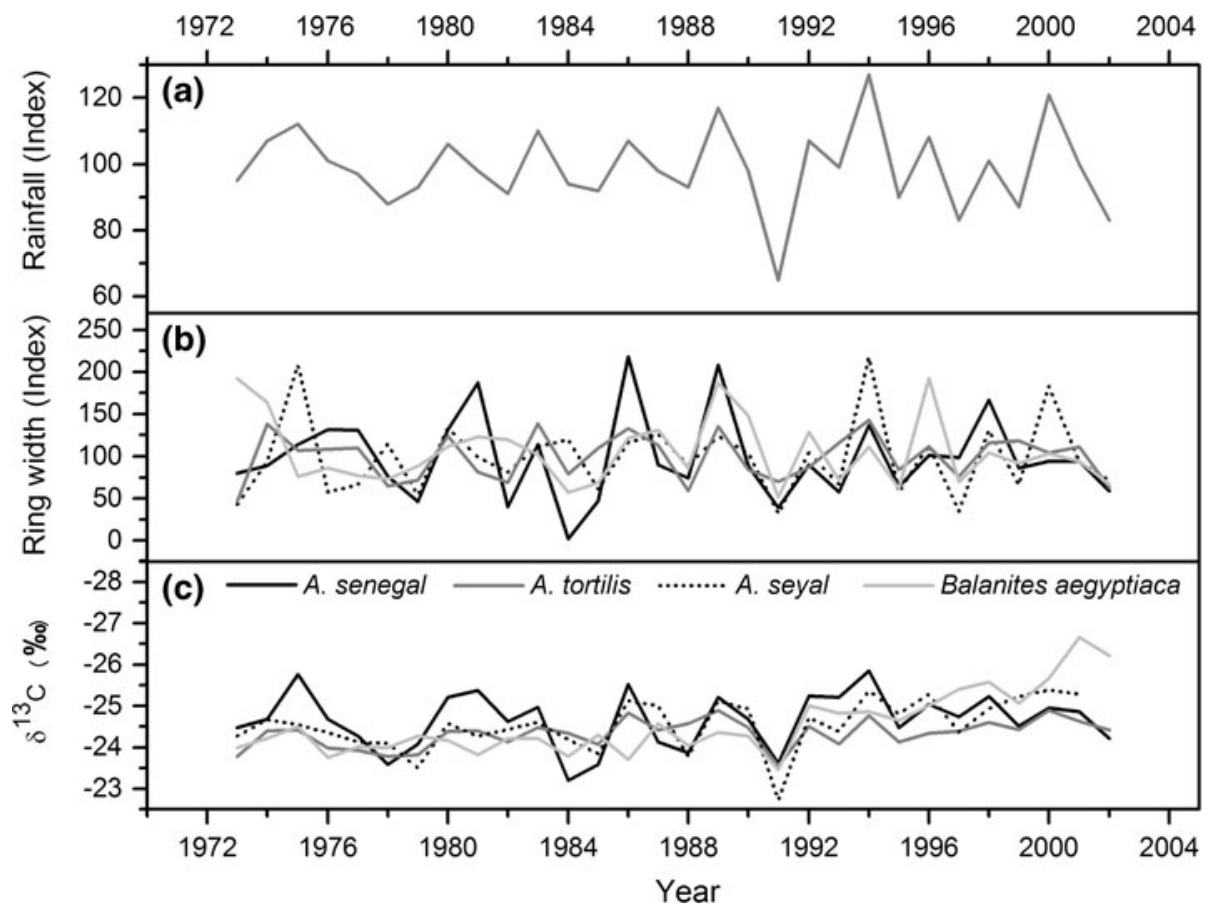

Table $2 \delta^{13} \mathrm{C}$ mean, maximum and minimum values of the study species (number of samples was 3 )

\begin{tabular}{llll}
\hline Species & Mean & Mean minimum & Mean maximum \\
\hline A. senegal & $-24.76 \pm 0.08 \mathrm{a}$ & $-26.28 \pm 0.26 \mathrm{a}$ & $-22.96 \pm 0.38$ \\
A. seyal & $-24.62 \pm 0.34 \mathrm{a}, \mathrm{b}$ & $-25.95 \pm 0.53 \mathrm{a}, \mathrm{b}$ & $-22.74 \pm 0.47$ \\
A. tortilis & $-24.31 \pm 0.25 \mathrm{~b}$ & $-25.07 \pm 0.30 \mathrm{~b}$ & $-23.49 \pm 0.12$ \\
B. aegyptiaca & $-24.48 \pm 0.38 \mathrm{a}, \mathrm{b}(-24.08)$ & $-25.92 \pm 1.02 \mathrm{a}, \mathrm{b}(-24.57)$ & $-23.32 \pm 0.21(-23.36)$ \\
\hline
\end{tabular}

Mean and standard error are shown for each variable. With in a column, means followed by different letters were statistically different at $P<0.05$. Values in brackets are excluding the data's of B. aegyptica from 1992 to 2003

$\delta^{13} \mathrm{C}$ (mean, maximum, minimum, and mean values for drought and moist years), ring width (mean, minimum, and maximum) and midday plant water potential values. The values for the last two parameters (Table 1) are refereed from our past research on plant water potential (Gebrekirstos et al. 2006) and climate growth relationships (Gebrekirstos et al. 2008). $\delta^{13} \mathrm{C}$ comparisons among the species were determined using one-way analysis of variance (ANOVA). STATISTICA for windows (Version 6.0) was used as a tool for the data analyses. Unless stated otherwise, results are statistically significant at $P<0.05$.

\section{Results}

Species-specific $\delta^{13} \mathrm{C}$ values

Mean $\delta^{13} \mathrm{C}$ values of the study species ranged from -24.31 to $-24.76 \%$, a total range of $0.45 \%$. Given a sample size of three, the standard error values obtained from all species falls between 0.08 and 0.38 (Table 2), indicating that the $\delta^{13} \mathrm{C}$ signature of individual trees remained close to the mean values. A. senegal had lower (more negative) mean and minimum $\delta^{13} \mathrm{C}$ values $(-24.76 \pm 0.08,-26.28 \pm$ $0.26 \%$ ) followed by $A$. seyal $(-24.62 \pm 0.34,-25.95 \pm$ $0.53 \%$ ). Mean, maximum and minimum $\delta^{13} \mathrm{C}$ values of A. senegal, A. seyal and B. aegyptiaca were not significantly different from each other. A. senegal showed a significant lower mean and minimum $\delta^{13} \mathrm{C}$ values than A. tortilis. A. tortilis showed no significant differences either with $A$. seyal or $B$. aegyptiaca. Though $A$. senegal and $A$. seyal showed the highest (less negative) maximum values, they showed no significant difference with B. aegyptiaca and A. tortilis. However, unlike the Acacias, B. aegyptiaca has showed a declining trend starting 1992 (Fig. 2c), and this has contributed to lower (more negative) values in the mean, minimum and maximum $\delta^{13} \mathrm{C}$. Excluding the 1991-2002 data resulted in less negative values (Table 2, values in brackets) compared to those of the Acacias.

Inter-annual variation (difference between maximum and minimum $\delta^{13} \mathrm{C}$ values) ranged from -22.22 to $-26.58 \%$, a total range of $3.8 \%$, with both extremes occurring in A. seyal 
Table 3 Two-sample tests of $\delta^{13} \mathrm{C}$ values of the species compared between drought years and other years for the period of 1973-2002

\begin{tabular}{|c|c|c|c|c|}
\hline \multirow[t]{2}{*}{ Chronologies } & \multicolumn{4}{|l|}{ Stable isotopes } \\
\hline & $\begin{array}{l}\text { Drought (years) } \\
(N=11)\end{array}$ & $\begin{array}{l}\text { Other (years) } \\
(N=19)\end{array}$ & $t$ value & $\begin{array}{l}\text { Significant } \\
\text { value }\end{array}$ \\
\hline A. senegal & $-24.27 \pm 0.63 \mathrm{a}$ & $-25.09 \pm 0.54 \mathrm{a}$ & 3.71 & 0.001 \\
\hline A. seyal & $-23.99 \pm 0.57 \mathrm{a}$ & $-24.82 \pm 0.33 \mathrm{a}$ & 4.30 & 0.00019 \\
\hline A. tortilis & $-24.08 \pm 0.32 \mathrm{a}$ & $-24.44 \pm 0.31 \mathrm{~b}$ & 3.43 & 0.02 \\
\hline B. aegyptiaca & $-24.27 \pm 0.55 \mathrm{a}$ & $-24.60 \pm 0.75 b$ & 1.25 & 0.22 \\
\hline
\end{tabular}

With in a column values separated by different letters were statistically different at $P<0.05$

$N$ number of years used for the analysis

and $A$. senegal, respectively. The highest range was that of A. seyal (2.37-3.71\%) followed by $A$. senegal (3.18-3.39\%o), while A. tortilis showed the lowest range (1.3-1.8\%o). On the other hand, inter-annual variation in B. aegyptiaca prior and after the declining trend in $\delta^{13} \mathrm{C}$ ranges from 1 to $3.48 \%$, respectively (Fig. 2c).

$\delta^{13} \mathrm{C}$ values in drought and moist years

Although the studied species revealed little differences in average mean values, they showed clear differences in drought and normal (moist) years (Fig. 2; Table 3). In all species, mean $\delta^{13} \mathrm{C}$ values in normal (moist years) were lower (more negative) than in drought years. Especially, A. senegal and A. seyal showed distinct variations between moist and dry years as compared with A. tortilis and B. aegyptiaca. B. aegyptiaca showed no significant difference between drought and moist years (Table 3).

Relationships between $\delta^{13} \mathrm{C}$, radial growth and plant water potential

The $\delta^{13} \mathrm{C}$ values and the respective ring width variations of all species showed negative correlations. Enriched $\delta^{13} \mathrm{C}$ values were found in narrow rings (drought years) compared to more depleted $\delta^{13} \mathrm{C}$ values in wide rings (moist years) (Table 3; Fig. 2).

Mean, minimum and maximum $\delta^{13} \mathrm{C}$ values of all the species were negatively correlated with mean, maximum and minimum radial growth, respectively (Fig. 3). In contrast, midday plant water potential showed positive correlation $(r=0.88)$ with mean and maximum radial growth but negative correlation with minimum radial growth (Fig. 4). Even more remarkable is the observed tendency for species having lower mean $\delta^{13} \mathrm{C}$ values to show high plant water potential (Figs. 3, 4) and, hence, better growth during moist years (Fig. 2). On the other hand, in drought years those species with lower water potentials (A. tortilis and B. aegyptiaca) showed better growth performances and lower mean $\delta^{13} \mathrm{C}$ values.

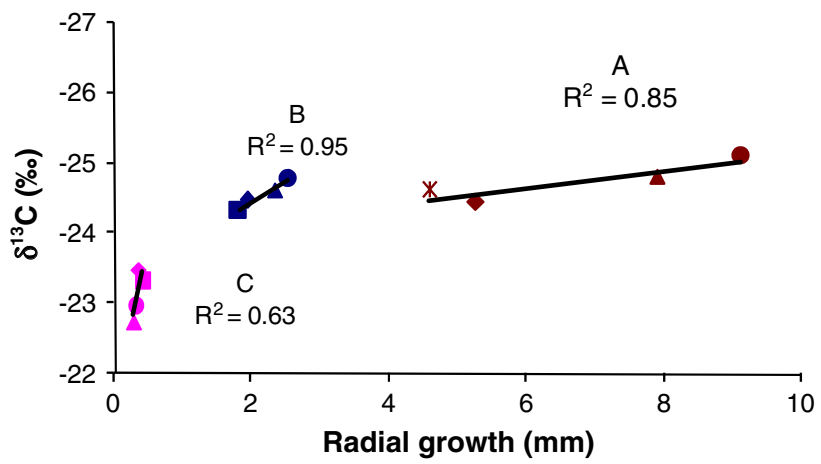

Fig. 3 Correlation coefficient of maximum $(A)$, mean $(B)$ and minimum growth rates of each species $(C)$ : filled circle (A. senegal), filled triangle (A. seyal), filled diamond (A. tortilis), filled square (B. aegyptiaca) with minimum, mean and maximum $\delta^{13} \mathrm{C}$ values of each species, respectively

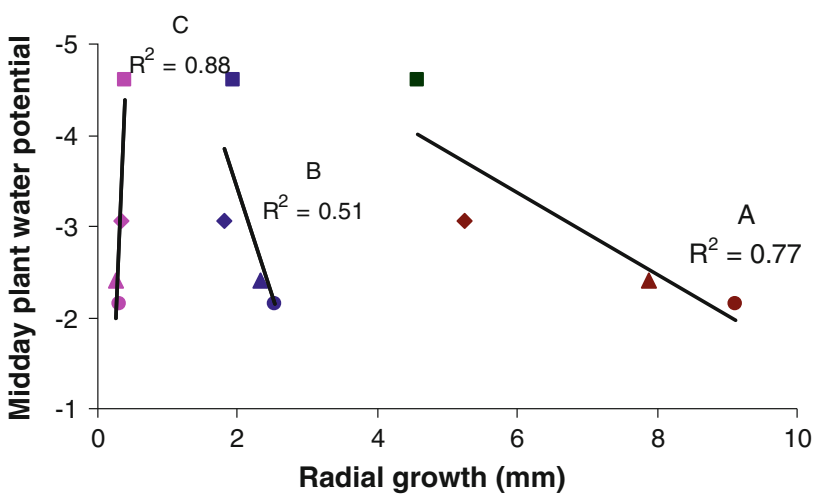

Fig. 4 Correlation coefficient of maximum $(A)$, mean $(B)$ and minimum growth rates of each species $(C)$ : filled circle (A. senegal), filled triangle (A. seyal), filled diamond (A. tortilis), filled square (B. aegyptiaca) with midday plant water potential of each species $(r=0.88,0.72$ and -0.93 , respectively)

\section{Discussion}

After correcting annual wood tissue $\delta^{13} \mathrm{C}$ for atmospheric changes in $\delta^{13} \mathrm{C}$, carbon isotopic composition ranged from -26.58 to $-22.22 \%$, which falls within the range observed in C3 plants (-32 to $-20 \%$ ) (Ehleringer 1993). However, 
the range of mean values $(<1 \%)$ obtained within and among the investigated species is very small compared to similar studies elsewhere. For instance, Ramesh et al. (1985) found differences of ca. 3\%o between four conifer species in the Kashmir Valley of India and Hemming et al. (1998) found a difference of ca. 2.5\% in Eastern England. McCarroll and Pawellek (1998) found a range of 2.15\% within Pinus sylvestris. Others have reported that differences of individuals within a species, even growing at the same site, can be as large as differences found between species (Leavitt and Long 1984; Leavitt and Lara 1994; Brendel et al. 2002). Although not statistically significant, mean values of $A$. senegal and $A$. seyal show lower (more negative) $\delta^{13} \mathrm{C}$ values compared to $A$. tortilis and $B$. aegyptiaca. This can be attributed to their water use strategy, which will be discussed below.

The higher interannual fluctuation in $\delta^{13} \mathrm{C}$ values in $A$. senegal and $A$. seyal compared to $A$. tortilis and $B$. aegyptiaca (Fig. 2) may indicate that $A$. senegal and A. seyal did not maintain a consistent stomatal response under conditions of changing water availability. This is reflected by higher (more negative) $\delta^{13} \mathrm{C}$ values in moist years (Table 3) which may reflect improved stomatal conductance. However, A. tortilis and B. aegyptiaca showed a lower decrease in $\delta^{13} \mathrm{C}$ values during moist years, indicating that stomatal regulation changed little between moist and dry years. This may be understood as a regulative adaptation of the trees to moisture stress in a way that uses constant stomatal closure as a set point for gas exchange. The lower midday water potential values of A. tortilis and B. aegyptiaca also support this interpretation.

In general, evergreen leaves tend to have lower stomatal conductance than deciduous leaves (Sobrado 1986, 1991). The lack of significant difference in $\delta^{13} \mathrm{C}$ values of $B$. aegyptiaca (evergreen species) in drought and moist years supports this general trend and thus it may be considered as an adaptive strategy. In contrast to the deciduous Acacias, however, the values of $B$. aegyptica showed a declining trend of $\delta^{13} \mathrm{C}$ after 1991 (Fig. 2) which is not accompanied by radial growth increments regardless of precipitation amounts. Excluding the 1991-2002 data, in the absence of clear understanding of its cause except assumptions (Gebrekirstos et al. 2009), resulted in higher $\delta^{13} \mathrm{C}$ values (less negative) compared to those of the Acacias and it fits to the general observation.

The underlying process which controls the $\delta^{13} \mathrm{C}$ ratio in C3 plants is well understood (Francey and Farquhar 1982; Farquhar et al. 1989). Photosynthetic fractionation of ${ }^{13} \mathrm{C}$ might explain the negative correlations found between $\delta^{13} \mathrm{C}$ and ring width and precipitation amount in this study. In drought years, the stomata will be more closed and hence the $C_{\mathrm{i}} / C_{\mathrm{a}}$ ratio will be relatively low because the $\mathrm{CO}_{2}$ supply through the stomata is limited. However, in moist years, when drought stress is reduced, growth may increase along with increased stomatal conductance, resulting in wider rings and lower (more negative) $\delta^{13} \mathrm{C}$. Such a negative correlation between $\delta^{13} \mathrm{C}$ and ring width has been reported elsewhere (Tans and Mook 1980). Consistent with our reasoning, Treydte et al. (2001) found increasing carbon isotope ratios due to low air humidity or low soil moisture as a result of reduced stomatal conductance. In contrast, Saurer et al. (1997) reported a lack of correlation between ring width and $\delta^{13} \mathrm{C}$. They further commented that causal links should not be made between carbon isotope and ring width since the plant may vary stomatal conductance and photosynthetic capacity in common and $C_{\mathrm{i}}$ may be kept constant. This could be so as their tree-ring width variations were influenced by local growth conditions.

The observed relationships between $\delta^{13} \mathrm{C}$, radial growth and plant water potentials, allow further interpretation of the continuum between the two contrasting water use strategies and its consequences for competitive advantage and vegetation level complementarity. From our results it is apparent that $A$. senegal and $A$. seyal with the higher water potential values $(-1.55$ to $-2.68 \mathrm{MPa})$ tend to have low $\delta^{13} \mathrm{C}$ values (up to $-26.58 \%$ ) as well as better growth (up to $9.12 \mathrm{~mm}$ ) during moist years. During drought years, when soil water becomes very limiting, those species showed an enormous reduction in growth (up to $0.27 \mathrm{~mm}$ ) and increases in $\delta^{13} \mathrm{C}$ values (up to $-22.2 \%$ ). A. tortilis and $B$. aegyptiaca that exhibited low midday water potential values $(-3.05$ to $-4.61 \mathrm{MPa})$ showed significantly lower maximum growth during moist years (up to $5.25 \mathrm{~mm}$ ) but were able to maintain a relatively higher growth $(0.34 \mathrm{~mm})$ and showed smaller fluctuations in $\delta^{13} \mathrm{C}$ values in drought years (Table 3 ). In fact, $\delta^{13} \mathrm{C}$ values of $B$. aegyptiaca were lowered to below $-26 \%$ as a result of the declining trend but this was not accompanied by growth increase.

These differences between trees fit the pattern described by Ehleringer and Cooper (1988) of a negative correlation of potential growth rate and WUE when soil resources are not limited. Chapin (1991) has proposed that an essential trait of plants adapted to low resource environments is that they grow slowly even when an optimal supply of resources is provided.

Orwig and Abrams (1997), in their studies of radial growth responses to drought in the tree-ring records of six species growing within two locations of differing land-use history, canopy position and soil moisture characteristics, noted that during moist years, drought-sensitive species show enhanced growth than drought-tolerant species, while they show more reduced growth during drought years. A lower increase in WUE $\left(\delta^{13} \mathrm{C}\right.$ values $)$ under drier conditions by drought tolerant (Quercus ilex) compared to 
drought sensitive (Pinus halepensis) species has also been reported by Ferrio et al. (2003).

In a mixed vegetation, $A$. seyal and $A$. senegal would be favored during moist years because of their capacity for more rapid growth under wet conditions. On the other hand, A. tortilis and B. aegyptiaca have an advantage over A. seyal and A. senegal during dry years or dry environment as a consequence of a greater capacity for water conservation. Raddad and Lukkanen (2006) examined genetic variation in WUE and gum yield in A. senegal provenances grown on sandy and clay soil areas in Sudan. The clay provenances show more negative $\delta^{13} \mathrm{C}$ and higher growth rates indicating less conservative water use compared to sandy soil provenance. For dioecious trees the strategies may differ between male and female trees. Ward et al. (2002) reported that female Acer negundo trees show higher growth rates and lower isotope ratios in wet years, which imply that they are less conservative water users compared to male Acer negundo trees. However, alpha cellulose measurements of female and male Acer negundo trees did not differ during dry years, indicating that, on average, both maintained similar stomatal conductance under dry conditions.

\section{Conclusions}

Our study revealed that the $\delta^{13} \mathrm{C}$ of annual growth rings was negatively correlated with average annual radial growth ( $r=$ up to -0.77 ). Mean and maximum radial growth and plant water potential were positively correlated ( $r=0.87$ ), but negatively correlated with minimum growth. Remarkably, species with lower mean $\delta^{13} \mathrm{C}$ values tend to show high plant water potential and, hence, better growth during moist years. On the other hand, in drought years those species with lower water potentials showed relative better growth performances (reflected by negative correlation with minimum growth) and less increase in $\delta^{13} \mathrm{C}$ values. Consequently, $A$. senegal and $A$. seyal are characterized as low WUE and opportunistic water users while A. tortilis and B. aegyptiaca are high WUE and conservative water users. From our results it is evident that $\delta^{13} \mathrm{C}$ signatures in tree rings are able to reflect life time reaction of the tree to water availability changes and, therefore, $\delta^{13} \mathrm{C}$ in tree rings can be useful to screen species for agroforestry and in restoration/reforestation of degraded lands. However, in order to use $\delta^{13} \mathrm{C}$ effectively in a program to select trees for stressful site conditions, we recommend applying an integrated approach. Based on these findings, if survival under drought and maintaining acceptable growth under water limited conditions are both critical, species with high $\delta^{13} \mathrm{C}$ values (high WUE plants) or species with low water potential values would have a better survival and increment than low WUE plants.
Therefore, they would be more suitable for planting in arid areas. Under conditions where water is limiting, but relatively high soil moisture is available, and of course under non-limiting water conditions, species with low WUE are better competitors.

We recommend that future studies investigate whether the relationships and differences between the species observed in this study are also pertinent in other environmental settings.

Acknowledgments The study was financed by the German Academic Exchange Service (DAAD), which is gratefully acknowledged. We thank Wondo Genet College of Forestry, Hawassa University for logistic support. We extend our thank to the staff members of Abernosa Ranch for their kind assistance and logistic support during the fieldwork.

Open Access This article is distributed under the terms of the Creative Commons Attribution Noncommercial License which permits any noncommercial use, distribution, and reproduction in any medium, provided the original author(s) and source are credited.

\section{References}

Azene-Bekele T, Birne A, Tengnas B (1993) Useful trees and shrubs for Ethiopia: Identification, propagation and management for agricultural and pastoral communities. Regional Soil Conservation Unit, RSCU/SIDA, Nairobi

Breda NH, Cochard E, Dreyer Granier A (1993) Water transfer in a mature oak stand (Quercus petraea): seasonal evolution and effects of a severe drought. Can J For Res 23:1136-1143

Brendel O, Pot D, Plomion C, Rozenberg P, Guehl JM (2002) Genetic parameters and QTL analysis of $\delta^{13} \mathrm{C}$ and ring width in maritime pine. Plant Cell Environ 25:945-953

Chapin FS III (1991) Integrated responses of plants to stress. Bioscience 41:29-36

Dawson IK, Lengkeek A, Weber JC, Jamnadas R (2009) Managing genetic variation in tropical trees: linking knowledge with action in agroforestry ecosystems for improved conservation and enhanced livelihoods. Biodivers Conserv 18:969-986

Ehleringer JR (1993) Carbon and water relations in desert plants: an isotopic perspective. In: Ehleringer JR, Hall AE, Farquhar GD (eds) Stable isotopes and plant carbon-water relations. Academic Press, San Diego, pp 155-172

Ehleringer JR, Cooper TA (1988) Correlations between carbon isotope ratio and microhabitat in desert plants. Oecologia 76:562-566

Farquhar GD, O'Leary MH, Berry JA (1982) On the relationship between carbon isotope discrimination and intercellular carbon dioxide concentration in leaves. Aust J Plant Physiol 9:121-137

Farquhar GD, Hubick KT, Condon AG, Richards RA (1988) Carbon isotope fractionation and plant water-use efficiency. In: Rundel PW, Ehleringer JR, Nagy KA (eds) Stable isotopes in ecological research. Springer, New York, pp 21-40

Farquhar GD, Ehleringer JR, Hubick KT (1989) Carbon isotope discrimination and photosynthesis. Annu Rev Plant Physiol Plant Mol Biol 40:503-537

Ferrio JP, Florit A, Vega A, Serrano L, Voltas J (2003) $\delta^{13} \mathrm{C}$ and treering width reflect different drought responses in Quercus ilex and Pinus halepensis. Oecologia 137:512-518 
Francey RJ, Farquhar GD (1982) An explanation of ${ }^{13} \mathrm{C} /{ }^{12} \mathrm{C}$ variations in tree rings. Nature 297:28-31

Gebrekirstos A (2006) Stable carbon isotopes and plant water relations in the Acacia Savanna Woodlands of Ethiopia: implications for reforestation and paleoclimatic reconstructions. PhD Thesis, Goettingen University, Cuvillier Verlag Goettingen, Germany

Gebrekirstos A, Demel T, Masresha F, Mitlöhner R (2006) Adaptation of five co-occurring tree and shrub species to water stress and its implication in restoration of degraded lands. For Ecol Manag 229:259-267

Gebrekirstos A, Mitlöhner R, Demel T, Worbes M (2008) Climategrowth relationships of the dominant tree species from semi-arid savannah woodland in Ethiopia. Trees 22:631-641

Gebrekirstos A, Teketay D, Fetene M, Worbes M, Mitlöhner R (2009) Stable carbon isotope ratios in tree rings of co-occurring species from semi arid tropics in Africa: patterns and climatic signals. Glob Planet Change 66:253-260

Hedberg I, Edwards S (1989) Flora of Ethiopia, vol 3. The National Herbarium, Addis Ababa University, Addis Ababa, Ethiopia and Department of Systematic Botany, Uppsala University, Uppsala

Hemming DL, Switsur VR, Waterhouse JS, Heaton THE, Carter AHC (1998) Climate and stable carbon isotope composition of tree ring cellulose: an intercomparison of three tree species. Tellus B $50: 25-32$

IPCC (Intergovernmental Panel on Climate Change (2007) Climate change 2007: climate change impacts, adaptation and vulnerability, IPCC WGII Fourth Assessment Report. http://www.ipcc. ch/SPM6avr07.pdf

Ladiges PY (1975) Some aspects of tissue water relations in three populations of Eucalyptus viminalis Labill. New Phytol 75:53-62

Leavitt SW, Lara A (1994) South American tree rings show declining $\delta^{13} \mathrm{C}$ trend. Tellus B 46:152-157

Leavitt SW, Long A (1984) Sampling strategy for stable carbon isotope analysis of tree rings in pine. Nature 301:145-147

Macfarlane C, Adams MA (1998) $\delta^{13} \mathrm{C}$ of wood in growth-rings indicates cambial activity of drought stressed trees of Eucalyptus globules. Funct Ecol 12:655-664

Makin MJ, Kingham JJ, Waddams AE, Birchall CJ, Tamene T (1975) Development prospects in the southern Rift Valley, Ethiopia. Land Resource Division, Ministry of Overseas Development, England

McCarroll D, Loader NJ (2004) Stable isotopes in tree rings. Quat Sci Rev 23:771-801
McCarroll D, Pawellek F (1998) Stable carbon isotope ratios of latewood cellulose in Pinus sylvestris from northern Finland: variability and signal strength. Holocene 8:693-702

Orwig DA, Abrams MD (1997) Variation in radial growth responses to drought among species, site and canopy strata. Trees 11:474-484

Poschen P (1986) An evaluation of the Acacia albida-based agroforestry practices in the Hararghe highlands of Eastern Ethiopia. Agrofor Syst 4:129-143

Raddad YE, Lukkanen O (2006) Adaptive genetic variation in water use-efficiency and gum yield in Acacia senegal provenances grown on clay soil in the Blue Nile region, Sudan. For Ecol Manag 226:219-229

Ramesh R, Bhattacharya SK, Gopalan K (1985) Dendroclimatological implications of isotope coherence in trees from Kashmir Valley, India. Nature 317:802-804

Saurer M, Borella S, Schweingruber F, Siegwolf R (1997) Stable carbon isotopes in tree rings of beech: climatic versus siterelated influences. Trees 11:291-297

Scholander PF, Hammel HT, Bradstreet ED, Hemmingsen EA (1965) Sap pressure in vascular plants. Science 148:339-346

Sobrado MA (1986) Aspects of tissue water relations and seasonal changes of leaf water potential components of evergreen and deciduous species coexisting in tropical dry forest. Oecologia 68:413-416

Sobrado MA (1991) Cost-benefit relationships in deciduous and evergreen leaves of tropical dry forest species. Funct Ecol 5:608-616

Tans P, Mook WG (1980) Past atmospheric $\mathrm{CO}_{2}$ levels and the ${ }^{13} \mathrm{C} /{ }^{12} \mathrm{C}$ ratios in tree rings. Tellus $32: 268-283$

Treydte K, Schleser GH, Schweingruber FH, Winiger M (2001) The climatic significance of $\delta^{13} \mathrm{C}$ in subalpine spruces (Lötschental, Swiss Alps). Tellus B 53:593-611

Van Noordwijk M (1984) Ecology textbook for the Sudan. Khartoum University Press, Sudan

Vertovec M, Sakcali S, Ozturk M, Salleo S, Giacomich P, Feoli E, Nardini A (2001) Diagnosing plant water status as a tool for quantifying water stress on a regional basis in Mediterranean drylands. Ann For Sci 58:113-125

Walter H (1973) Vegetation of the earth in relation to climate and ecophysiological conditions. Springer, New York, pp 237

Ward JK, Dawson TE, Ehleringer JR (2002) Responses of Acer negundo genders to inter- annual differences in water availability determined from carbon isotope ratios of tree ring cellulose. Tree Physiol 22:339-346 